\title{
Indomie Noodle Healthy Formulae Instead of the Commercial Formula
}

\author{
Eshak M. El-Hadidy¹, Saeed S. Salam² \\ ${ }^{1}$ Food Technology Research Institute, Agriculture Research Center, Giza, Egypt \\ ${ }^{2}$ Food Control Department, Veterinary Medicine Faculty, Cairo University, Giza, Egypt \\ Email: emgelhadidy1973@gmail.com
}

How to cite this paper: El-Hadidy, E.M. and Salam, S.S. (2017) Indomie Noodle Healthy Formulae Instead of the Commercial Formula. Food and Nutrition Sciences, 8, 1093-1104.

https://doi.org/10.4236/fns.2017.812081

Received: November 4, 2017

Accepted: December 12, 2017

Published: December 18, 2017

Copyright () 2017 by authors and Scientific Research Publishing Inc. This work is licensed under the Creative Commons Attribution International License (CC BY 4.0).

http://creativecommons.org/licenses/by/4.0/

(c) (i) Open Access

\begin{abstract}
This investigation was carried out to evaluate some different seasoning made of onion, garlic, red chili, oregano, marjoram, basil, rosemary, cumin and black pepper to give light and healthy formulae to add to instant indomie noodle. Antioxidants were assessed in raw materials and their formulae, also sensory properties were evaluated in different instant indomie noodle seasoning formulae. The results in raw materials explored that the seasoning contains large amounts of antioxidants content, total carotenoids, volatile oil and antioxidant activity compared with the commercial formula. Corn oil was used as a carrier for the commercial formula and separated three tested spice formulae in ratio 1:100 w/w. Three chosen tested formulas; onion, garlic, red chili 1); oregano, marjoram, basil 2) and rosemary, cumin, black pepper 3) were used in the research. The results indicated that formula 3 has higher antioxidant activity $(119.00 \%)$ than formula 1 and $2(83.33 \%$ and $62.33 \%$, respectively). Meanwhile, the results from sensory evaluation showed that no significant difference appeared from the different spice formulae. Biological experiment was carried out for these formulae and measured the liver reduced glutathione (GSH), superoxide dismutase (SOD), malonaldehyde (MDA), serum liver enzymes aspartate and alanine aminotransferases and alkaline phosphatase (AST, ALT and ALP), serum total protein, albumin and globulin also, renal function (uric acid, urea and creatinine) in rats fed on basal diet including oil carried the commercial formula or instant indomie noodle tested seasoning formulae. The results illustrated that the different instant indomie noodle seasoning formulae gave better results than the commercial formula in liver and renal functions. It could be recommended that consuming the suggested different seasoning formulae instead of the commercial questioned one as sodium glutamate prevent many harmful effects. It should be done occasionally, especially when the need for indomie noodles arises especially for children. This is because it contains the necessary nutrients as antioxidants and acceptable taste for healthy living in moderate proportion.
\end{abstract}




\section{Keywords}

Indomie Noodles, Seasoning Formulae, Sensory Evaluation, Antioxidant Activity, Male Albino Rats, Liver and Renal Functions

\section{Introduction}

Herbs and spices contain high levels of antioxidant compounds, which provide protection against harmful free radicals and have been associated with a number of health benefits [1] [2]. Herbs have been used for a large range of purposes including medicine, nutrition, flavorings, beverages, dyeing, repellents, fragrances, cosmetics, charms, smoking, and industrial uses. Since prehistoric times, herbs were the basis for of nearly all medicinal therapy until synthetic drugs were developed in the nineteenth century. Today herbs are still found in 40 percent of prescription drugs [3]. Culinary herbs have been grown and used for hundreds of years, and they are becoming increasingly popular in the United States for their ability to enhance and complement the flavors of a wide variety of foods [4].

Culinary herbs and spices have been long used as preservative agents to extend the shelf-life of food and also to enhance or improve the flavor and organoleptic properties of different types of food due to their sensory properties [5].

Phytochemicals in herbs and spices that are beneficial for human health, polyphenols are an attractive target, due to their antimicrobial, digestive stimulant, anti-inflammatory, antioxidant and anticarcinogenic activities. Also, flavonoids and hydroxycinnamic acids provide free-radical scavenging, modulation of enzymatic activity, metal chelation and inhibition of cellular proliferation. Additionally, polyphenols can extend the shelf-life of lipid-rich foods [6].

Indomie is a brand of instant noodles by Indofood, the world's largest instant noodle manufacturer, located in Indonesia. Indofood is one of the world's largest manufacturers of dried instant noodles based in Indonesia. Theindomie (the name derived from the Indonesian MiGoreng, which means fried noodle) is an instant noodle sold dried in packets or cups. The noodles are quick and easy to make, and can be eaten as a snack or as part of a main meal. Their versatility means that people can carry them to work or on trips, and cook them simply by adding hot water from a kettle [7].

Indomie noodles are consumed in large quantities worldwide. There is a public health concern about the possible mutagenic and genotoxic effects the seasoning might have on the consumers, especially on children of different developmental stages [8].

Indomie noodles is usually prepared for consumption using its seasoning, therefore, the rate at which indomie noodles is consumed is proportional to the rate at which the seasoning is consumed. The major constituents of indomie noodle are wheat flour, vegetable oil, iodized salt, sodium polyphosphate, sodium carbonate, potassium carbonate, guar gum and tartrazine, while that of the 
seasoning powder are iodized salt, mono sodium glutamate (MSG, E-621), hydrolyzed vegetable protein, soy powder, garlic powder, chicken flavor and chili powder [9]. The study of the same authors where indomie noodles spiced with the seasoning educed the activities of alanine aminotransferase, an important antioxidant enzyme.

In the Modern World, the entrance of Chinese, Japanese, and ready to serve foods like 2-minute noodles, soups, sauces, etc., all containing monosodium glutamate (MSG), has tremendously increased especially in younger generation because of its palate pleasing favorite flavor. In the present era, MSG, an inducer of oxidative stress [10].

Indomie noodles contain also, tartrazineas a synthetic lemon yellow azo dye primarily used as food coloring agent [11]. Tartrazine was believed to cause most of the allergic and intolerance reaction experienced amongst all the azo dyes, particularly in asthmatic patients and those with aspirin intolerance.

The aim of this investigation was carried out to evaluate some different spices made from onion, garlic, red chili, oregano, marjoram, basil, rosemary, cumin and black pepper to give three light and healthy formulae and it was added to instant indomie noodle. Total polyphenols, total flavonoids, total carotenoids, volatile oil and antioxidant activity were determined in raw materials and their formulae. Sensory properties and biological experimental (liver and renal functions) were evaluated using different formulae.

\section{Materials and Methods}

\subsection{Materials}

Powder materials (onion, garlic, chili, basil, oregano, marjoram, rosemary, cumin and black pepper) passed through the sieve 50 mesh was collected from herbs and Spices Company in Obour City, El Kalubia Governorate-Egypt. Preparation of different formulae is showed in Table 1.

\subsection{Antioxidant Analyses}

Total polyphenols, total flavonoids, total carotenoids, volatile oil and DPPH were determined in onion, garlic, red chili, oregano, marjoram, basil, rosemary, cumin black pepper and their formulae.

Table 1. Different instant indomienoodle seasoning formulae.

\begin{tabular}{ccc}
\hline Formulae & Components & Mixture Ratio \\
\hline Control & $\begin{array}{c}\text { Monosodium glutamate (E-621), artificial } \\
\text { chicken flavor powder, yeast extract, onion } \\
\text { powder, garlic powder, ginger powder, pepper } \\
\text { powder, chili powder, salt }\end{array}$ & Seasonings commercial powder \\
Formula 1 & Onion:Garlic:Red chili:Salt & $2: 1: 1: 0.1$ \\
Formula 2 & Oregano:Marjoram: Basil:Salt & $2: 1: 1: 0.1$ \\
Formula 3 & Rosemary:Cumin:Black pepper:Salt & $2: 1: 1: 0.1$ \\
\hline
\end{tabular}


Total polyphenolic contents were measured using Folin-Ciocalteu method described by [12]. Also, total flavonoids content as rutin was determined by [13]. Total carotenoids as $\beta$-carotene was determined according to [14]. Ascorbic acid was determined according to the methods of [15]. Volatile oil was determined by International Standard Organization method [16].

The antioxidant activity was determined in different formulae using the 1,1diphenylpicrylhydrazyl (DPPH) assay described by [17] .

\subsection{Sensory Evaluation}

Sensory evaluation was carried out in order to get consumer response for overall acceptability of the different spices formulae compared to the control commercial spice. Products were evaluated by a panel of 10 judges for different sensory attributes like flavor, taste and overall acceptability according to [18].

\subsection{Biological Experiment}

Male Albino rats strain (30 animals, 6 rats for each group) weighting 160 - $180 \mathrm{~g}$ provided from Animal house in Food Technology Research Institute, Agricultural Research Center, Giza-Egypt. Animals were housed in individual cages with screen bottoms and fed on basal diet for one week. It consisted of casein $15 \%$, corn oil $10 \%$, fiber as cellulose $5 \%$, salt mixture $4 \%$, vitamin mixture $1 \%$ and corn starch $65 \%$ [19].

One gram from commercial formula or different seasonings formulae included in Table 1 were taken and added separately to every $100 \mathrm{~g}$ of corn oil. The oil was left mixed in dark bottles and dark place for a day then filtered the corn oil to give corn oil as a carrier with commercial formula and three different spices formulae were used to biological experimental.

The experimental animals were randomly assigned into five groups. Group 1 as a normal control group, rats were fed on basal diet towards to the end of experimental period. Meanwhile, groups 2, 3, 4 and 5 rats were fed on the basal diet consisted of casein $15 \%$, separately corn oil as a carrier with commercial formula or different spices formulae $10 \%$, cellulose $5 \%$, salt mixture $4 \%$, vitamin mixture $1 \%$ and corn starch $65 \%$ for four weeks.

At the end of experimental period (4-weeks), all animals were sacrificed and blood was collected to separate serum for serum parameters. Liver was excised out, washed in saline and preserve in $10 \%$ formalin for lipid peroxidation analysis in liver.

In liver, reduced glutathione (GSH) was determined colorimetric method described by [20], superoxide dismutase (SOD) was measured using the method described by [21]. Malonaldehyde (MDA) was analyzed according to the method of [22].

Serum Aspartate aminotransferease (AST) and alanine aminotransferease (ALT) were determined according to [23], while serum alkaline phosphatase (ALP) detected according to [24]. Total protein, albumin and globulin were determined according to [25]. Serum uric acid was determined by the enzymatic 
colorimetric method which described by [26]. Urea was determined by using the method of [27]. Creatinine was determined by the method of [28].

\subsection{Statistical Analyses}

Statistical analysis was carried out using Statistical Package for Social Sciences (SPSS) for windows, Version 20 (SPSS Inc., Chicago, IL, USA). Collected data was presented as mean \pm standard deviation (SD). Analysis of variance (ANOVA) test was used for determining the significances among different groups according to [29]. All differences were consider significant $(\mathrm{P}<0.05)$.

\section{Results and Discussion}

\subsection{Antioxidant Assessment in Raw Materials and Their Different Formulae}

Total polyphenols, total flavonoids, total carotenoids, volatile oil and antioxidant activity were determined in raw materials and their formulae and the results are reported in Table 2 and Table 3. Data in Table 2 shows that the marjoram and oregano were higher contents in polyphenols $(22.32$ and $20.17 \mathrm{mg} / \mathrm{g}$, respectively) than other condiments. Meanwhile, red chili was the highest content of total flavonoids in $(13.02 \mathrm{mg} / \mathrm{g})$ followed by black pepper, rosemary and marjoram (4.20, 3.80 and $2.70 \mathrm{mg} / \mathrm{g}$, respectively). Clearly, black pepper, cumin then red chili were the highest content of total carotenoids $(116.23,76.24$ and $61.30 \mathrm{mg} / \mathrm{g}$, respectively). Also, red chili was the best in volatile oil content $(2.32 \mathrm{~mL} / 100 \mathrm{~g})$ and then oregano, cumin and black pepper were $1.83,1.63$ and $1.55 \mathrm{~mL} / 100 \mathrm{~g}$, respectively. These results is occurred by [30] who found the herbs contain large amounts of antioxidants other than vitamin $\mathrm{C}$, vitamin $\mathrm{E}$ and carotenoids. The antioxidant effect is mainly due to phenolic components, such as flavonoids, phenolic acids, and phenolic diterpenes. Herbs have been investigated for their quenching activity of reactive oxygen species.

Table 2. Antioxidants content and its activities in different seasoning (mg/g).

\begin{tabular}{cccccc}
\hline Raw Materials & $\begin{array}{c}\text { Total } \\
\text { Polyphenols }\end{array}$ & $\begin{array}{c}\text { Total } \\
\text { Flavonoids }\end{array}$ & $\begin{array}{c}\text { Total } \\
\text { Carotenoids }\end{array}$ & $\begin{array}{c}\text { Volatile Oil } \\
(\mathrm{mL} / 100 \mathrm{~g})\end{array}$ & $\begin{array}{c}\text { Antioxidant } \\
\text { Activity }(\%)\end{array}$ \\
\hline Onion & $7.23 \pm 0.84^{*}$ & $1.82 \pm 0.13$ & $0.73 \pm 0.12$ & $0.23 \pm 0.03$ & $52.00 \pm 3.22$ \\
Garlic & $3.24 \pm 0.33$ & $0.90 \pm 0.11$ & $1.20 \pm 0.25$ & $0.09 \pm 0.01$ & $48.00 \pm 2.46$ \\
Red chili & $4.15 \pm 0.25$ & $13.02 \pm 0.73$ & $61.30 \pm 0.08$ & $2.32 \pm 0.18$ & $88.00 \pm 5.42$ \\
Oregano & $20.17 \pm 1.32$ & $1.54 \pm 0.12$ & $16.35 \pm 1.75$ & $1.83 \pm 0.67$ & $48.00 \pm 8.30$ \\
Basil & $4.82 \pm 0.22$ & $1.25 \pm 0.18$ & $6.42 \pm 1.34$ & $1.30 \pm 0.43$ & $62.00 \pm 7.55$ \\
Marjoram & $22.32 \pm 1.87$ & $2.70 \pm 0.26$ & $13.00 \pm 2.02$ & $0.8 \pm 0.20$ & $21.00 \pm 3.22$ \\
Rosemary & $12.04 \pm 8.23$ & $3.80 \pm 0.84$ & $3.0 \pm 0.21$ & $1.13 \pm 0.11$ & $35.32 \pm 0.04$ \\
Cumin & $10.30 \pm 0.65$ & $1.00 \pm 0.03$ & $76.24 \pm 2.45$ & $1.63 \pm 0.43$ & $82.00 \pm 8.43$ \\
Black pepper & $2.21 \pm 0.05$ & $4.20 \pm 0.54$ & $116.23 \pm 0.10$ & $1.55 \pm 0.32$ & $110.00 \pm 9.82$ \\
\hline
\end{tabular}

${ }^{*}$ Values are means of triplicates \pm Standard deviation. 
Table 3. Antioxidants content in different dry seasoning formulae.

\begin{tabular}{cccccc}
\hline Formulae & $\begin{array}{c}\text { Total Phenols } \\
(\mathrm{mg} / \mathrm{g})\end{array}$ & $\begin{array}{c}\text { Total Flavonoids } \\
(\mathrm{mg} / \mathrm{g})\end{array}$ & $\begin{array}{c}\text { Total Carotenoids } \\
(\mathrm{mg} / \mathrm{g})\end{array}$ & $\begin{array}{c}\text { Volatile Oil } \\
(\mathrm{mL} / 100 \mathrm{~g})\end{array}$ & $\begin{array}{c}\text { Antioxidant } \\
\text { Activity \% }\end{array}$ \\
\hline Formula 1 & $13.80 \pm 1.18^{*}$ & $6.42 \pm 0.84$ & $64.25 \pm 2.43$ & $1.12 \pm 0.10$ & $83.33 \pm 6.73$ \\
Formula 2 & $23.47 \pm 2.69$ & $1.39 \pm 0.23$ & $51.24 \pm 5.32$ & $1.98 \pm 0.16$ & $62.33 \pm 8.02$ \\
Formula 3 & $37.39 \pm 4.13$ & $2.26 \pm 0.40$ & $195.60 \pm 11.46$ & $2.03 \pm 0.24$ & $119.0 \pm 11.43$ \\
\hline
\end{tabular}

${ }^{*}$ Values are means of triplicates \pm Standard deviation.

According to formulae in Table 1, results in Table 3 illustrate formula 3 contained rosemary, cumin and black pepper mixture was rich in total polyphenols $(7.39 \mathrm{mg} / \mathrm{g})$, total carotenoids $(195.60 \mathrm{mg} / \mathrm{g})$ and volatile oil $(2.03 \mathrm{~mL} / 100 \mathrm{~g})$, while formula 1 had contained onion, garlic and red chili mixture was the highest content of total flavonoids $(6.42 \mathrm{mg} / \mathrm{g})$. The antioxidant contents reflected to DPPH activity, results indicated that formula 3 was higher antioxidant activity $(119.00 \%)$ than formulae 1 and 2 were 83.33 and $62.33 \%$, respectively.

The hydroxyl radical is an extremely reactive free radical formed in biological system and has been implicated as a highly damaging species in free radical pathology capable of damaging almost every molecule found in living cells. This species is considered to be one of the quick initiators of the lipid peroxidation process, abstracting hydrogen atoms from unsaturated fatty acids [31].

\subsection{Sensory Evaluation in Different Formulae}

Sensory properties were evaluated in instant noodle seasoning formulae and the results are reported in Table 4. From the resultant it could be noticed that the commercial formula was the lowest in taste, flavor and total acceptability (8.42, 8.50 and 8.30 , respectively). Meanwhile, the results showed that no significant differences were the different spice formulae. These means the raw materials spice had rich contained polyphenols, flavonoids compounds, total carotenoids and volatile oil.

Herbs and spices are not just valuable in adding flavor to foods. Their antioxidant activity also helps to preserve foods from oxidative deterioration, increasing their shelf-life. There has been increasing research in the role of herbs and spices as natural preservatives. Antioxidants, also play a role in the body's defense against cardiovascular disease, certain (epithelial) cancers and other conditions such as arthritis and asthma. Phenolic compounds such as flavonoids may help to protect against cardiovascular disease and intestinal cancer (black pepper, oregano, thyme and marjoram). Capsaicin in chili pepper is an effective counter-irritant used in both pharmaceuticals and cosmetics [32].

Herbs are generally composed of fiber, carbohydrate, fat, sugar, protein, gum, ash, antioxidant, volatile (essential) oil, and other nonvolatile components. All of these components impart each spice's particular flavor, color, nutritional, health, or preservative effects. The flavor components (volatile and nonvolatile) are protected within a matrix of carbohydrate, protein, fiber, and other cell 
Table 4. Sensory evaluation of commercial formula and instant noodle seasoning formulae.

\begin{tabular}{cccc}
\hline Formulae & Taste & Flavor & Overall Acceptability \\
\hline Commercial formula & $8.42 \pm 0.34^{\mathrm{b}}$ & $8.50 \pm 0.63^{\mathrm{b}}$ & $8.30 \pm 0.44^{\mathrm{b}}$ \\
Formula 1 & $9.35 \pm 0.42^{\mathrm{a}}$ & $9.43 \pm 0.50^{\mathrm{a}}$ & $9.46 \pm 0.66^{\mathrm{a}}$ \\
Formula 2 & $9.76 \pm 0.63^{\mathrm{a}}$ & $9.61 \pm 0.73^{\mathrm{a}}$ & $9.38 \pm 0.63^{\mathrm{a}}$ \\
Formula 3 & $9.55 \pm 0.52^{\mathrm{a}}$ & $9.52 \pm 0.65^{\mathrm{a}}$ & $9.47 \pm 0.59^{\mathrm{a}}$ \\
\hline
\end{tabular}

Data are presented as mean $(n=10$ panelist $) \pm$ standard deviation, values with different superscripts within the column are significantly difference at $\mathrm{P}<0.05$, while those with have similar or partially are not significant.

components. When the herbs is ground, cut, or crushed, this cell matrix breaks down and releases the volatile components [33].

\subsection{Biological Experimental}

\subsubsection{Effect of Instant Noodle Seasoning Formulae on Liver GSH, SOD and MDA Parameters}

Rats fed on diet containing seasoning formula 2 appeared to the highest increase significant in liver GSH (310.55 mg/g) then rats fed on diet containing formula 1 and 3 were 282.52 and $275.67 \mathrm{mg} / \mathrm{g}$, respectively compared to rats fed on diet containing commercial formula $(188.73 \mathrm{mg} / \mathrm{g})$. While, data indicated no significant variance between rats fed on diet containing formula 2 and normal rats fed on basal diet in normal control group (Table 5).

In parallel, liver SOD level in rats fed on diet contained formula 2 was the highest increase significant $(715.00 \mu \mathrm{g} / \mathrm{g})$ then rats fed on diet contained formula 1 then formula 3 (693.40 and $688.44 \mu \mathrm{g} / \mathrm{g}$, respectively) compared to rats fed on diet containing commercial mixture and normal control group.

In the same table, diet containing formulae 2 and 3 were significant decreased in rat's serum MDA level (8.99 and $9.32 \mathrm{nmol} / \mathrm{g}$, respectively) then formula 1 $(10.54 \mathrm{nmol} / \mathrm{g})$. While, no significant variances were observed in rats fed on formulae 2 and 3 which compared to serum MDA in rats fed on basal diet (8.02 $\mathrm{nmol} / \mathrm{g}$ ). Data indicated that the antioxidants content in seasoning formulae improve liver GSH, SOD and MDA levels.

These data complied to [34] they showed that, superoxide dismutase (SOD), catalase (CAT) and the enzyme of the glutathione redox cycle i.e. glutathione peroxidase (GSH-Px) and glutathione reductase (GSH-Rd) are the primary intracellular antioxidants and are considered to be preventive or primary, antioxidant as they prevent free radical chain reaction by decreasing the available concentration of free radical to initiate theprocess.

\subsubsection{Effect of Various Instant Noodle Seasoning Formulae on Serum AST, ALT and ALP Parameters}

Table 6 shows the effects of instant noodles seasoning formulae on liver function indices of rats. Feeding with the various seasoning formulated diets significantly reduced the activity of alanine transaminase (ALT) compared to control. The activity of aspartate transaminase (AST) was significantly reduced 
Table 5. Effect of instant noodle seasoning formulae on liver GSH, SOD and MDA parameters.

\begin{tabular}{cccc}
\hline Groups & GSH mg/g & SOD $\mu / g$ & MDA nmol/g \\
\hline Basal Diet & $290.54 \pm 18.54^{\mathrm{ab}}$ & $600.52 \pm 32.43^{\mathrm{c}}$ & $8.02 \pm 1.30^{\mathrm{c}}$ \\
Commercial & $188.73 \pm 12.74^{\mathrm{c}}$ & $470.63 \pm 27.42^{\mathrm{d}}$ & $14.20 \pm 1.98^{\mathrm{a}}$ \\
Formula 1 & $282.52 \pm 16.40^{\mathrm{b}}$ & $693.40 \pm 35.55^{\mathrm{ab}}$ & $10.54 \pm 1.62^{\mathrm{b}}$ \\
Formula 2 & $310.55 \pm 20.22^{\mathrm{a}}$ & $715.00 \pm 38.90^{\mathrm{a}}$ & $8.99 \pm 1.54^{\mathrm{c}}$ \\
Formula 3 & $275.67 \pm 18.47^{\mathrm{b}}$ & $688.44 \pm 33.65^{\mathrm{b}}$ & $9.32 \pm 1.89^{\mathrm{c}}$ \\
\hline
\end{tabular}

Data are presented as mean $(\mathrm{n}=6$ rats $) \pm$ standard deviation, values with different superscripts within the column are significantly difference at $\mathrm{P}<0.05$, while those with have similar or partially are not significant.

Table 6. Effect of various instant noodle seasoning formulae on serum AST, ALT and ALP parameters (IU/L).

\begin{tabular}{cccc}
\hline Groups & sAST & sALT & sALP \\
\hline Basal diet & $51.04 \pm 5.54^{\mathrm{b}}$ & $30.00 \pm 3.73^{\mathrm{b}}$ & $172.05 \pm 2.54^{\mathrm{b}}$ \\
Commercial formula & $72.33 \pm 3.88^{\mathrm{a}}$ & $40.04 \pm 5.44^{\mathrm{a}}$ & $225.00 \pm 5.50^{\mathrm{a}}$ \\
Formula 1 & $34.72 \pm 4.22^{\mathrm{c}}$ & $23.50 \pm 4.52^{\mathrm{c}}$ & $168.51 \pm 6.60^{\mathrm{b}}$ \\
Formula 2 & $35.54 \pm 4.10^{\mathrm{c}}$ & $25.00 \pm 5.55^{\mathrm{c}}$ & $165.70 \pm 8.44^{\mathrm{b}}$ \\
Formula 3 & $23.88 \pm 6.36^{\mathrm{d}}$ & $18.98 \pm 8.43^{\mathrm{d}}$ & $170.32 \pm 4.62^{\mathrm{b}}$ \\
\hline
\end{tabular}

Data are presented as mean ( $\mathrm{n}=6$ rats) \pm standard deviation, values with different superscripts within the column are significantly difference at $\mathrm{P}<0.05$, while those with have similar or partially are not significant.

in the groups 3 instant noodles seasoning formula and increased significantly in the group fed commercial formula to control. While, rats fed on different seasoning formulae were significant decrease in sALP (168.51, 164.70 and 170.32 IU/L, respectively) compared to rats fed on diet containing commercial formula (225.00 IU/L). Also, Data indicates no significant variance between seasoning formula groups.

The above may be due to the activity of ALT and AST in the serum are markers of liver injury [35]. Changes in the activities of these enzymes indicate injury to organelles such as mitochondria leading to release of soluble enzymes like AST [36].

\subsubsection{Effect of Various Instant Noodle Seasoning Formulae on Total Protein, Albumin and Globulin}

Concentrations of albumin, bilirubin and total protein in the blood can indicate the functional state of the liver [37]. Albumin in conjunction with other plasma proteins exerts a colloidal osmotic pressure which serves to maintain a normal blood volume. Thus, the decrease in serum albumin and protein concentration might be due to a diminished synthetic function of the liver [38].

Results in Table 7 refer to serum total protein, albumin and globulin contents in rats fed on different formula compared to rats fed on commercial formula or basil diet. The results show a significant decrease in total protein $(4.35,4.66,4.43$ and $5.92 \mathrm{~g} / \mathrm{dL}$, respectively) and albumin $(3.20,3.12,3.25$ and $3.99 \mathrm{~g} / \mathrm{dL}$, 
Table 7. Effect of various instant noodle spices formulas on serum total protein, albumin and globulin $(\mathrm{g} / \mathrm{dL})$.

\begin{tabular}{cccc}
\hline Groups & Total Protein & Albumin & Globulin \\
\hline Basal diet & $5.11 \pm 0.98^{\mathrm{ab}}$ & $3.58 \pm 0.52^{\mathrm{ab}}$ & $2.60 \pm 0.44^{\mathrm{ab}}$ \\
Commercial formula & $5.92 \pm 0.27^{\mathrm{b}}$ & $3.99 \pm 0.12^{\mathrm{b}}$ & $1.98 \pm 0.10^{\mathrm{b}}$ \\
Formula 1 & $4.35 \pm 0.66^{\mathrm{a}}$ & $3.20 \pm 0.42^{\mathrm{a}}$ & $2.67 \pm 0.27^{\mathrm{a}}$ \\
Formula 2 & $4.66 \pm 0.76^{\mathrm{a}}$ & $3.12 \pm 0.50^{\mathrm{a}}$ & $2.67 \pm 0.26^{\mathrm{a}}$ \\
Formula 3 & $4.43 \pm 0.55^{\mathrm{a}}$ & $3.25 \pm 0.33^{\mathrm{a}}$ & $2.71 \pm 0.23^{\mathrm{a}}$ \\
\hline
\end{tabular}

Data are presented as mean $(\mathrm{n}=6$ rats $) \pm$ standard deviation, values with different superscripts within the column are significantly difference at $\mathrm{P}<0.05$, while those with have similar or partially are not significant.

Table 8. Effect of various instant noodle seasoning formulae on renal functions parameters $(\mathrm{mg} / \mathrm{dL})$.

\begin{tabular}{cccc}
\hline Groups & Uric acid & Urea & Creatinine \\
\hline Basal diet & $3.23 \pm 0.52^{\mathrm{b}}$ & $39.43 \pm 2.43^{\mathrm{b}}$ & $0.68 \pm 0.12^{\mathrm{b}}$ \\
Commercial formula & $3.90 \pm 0.98^{\mathrm{a}}$ & $50.56 \pm 5.42^{\mathrm{a}}$ & $1.02 \pm 0.23^{\mathrm{a}}$ \\
Formula 1 & $1.89 \pm 0.31^{\mathrm{c}}$ & $31.66 \pm 7.30^{\mathrm{bc}}$ & $0.62 \pm 0.08^{\mathrm{b}}$ \\
Formula 2 & $2.00 \pm 0.55^{\mathrm{c}}$ & $29.80 \pm 6.66^{\mathrm{c}}$ & $0.60 \pm 0.09^{\mathrm{b}}$ \\
Formula 3 & $1.95 \pm 0.20^{\mathrm{c}}$ & $29.14 \pm 6.05^{\mathrm{c}}$ & $0.58 \pm 0.08^{\mathrm{b}}$ \\
\hline
\end{tabular}

Data are presented as mean $(n=6$ rats $) \pm$ standard deviation, values with different superscripts within the column are significantly difference at $\mathrm{P}<0.05$, while those with have similar or partially are not significant.

respectively) in rats fed on seasoning formulae compared to commercial formula, respectively. In contrast, there was an increase in globulin in rats fed on seasoning formula compared with commercial formula $(2.67,2.67,2.71$ and 1.98 $\mathrm{g} / \mathrm{dL})$, respectively.

\subsubsection{Effect of Various Instant Noodle Seasoning Formulae on Renal Functions Parameters}

Urea, the major product of protein catabolism measuring urea is the most popular laboratory procedure for assessing renal function [39]. Creatinineis a catabolic product of creatine phosphate, which is used in skeletal muscle concentration [40]. In the skeletal muscle serum creatinine levels are elevated by renal disease and dehydration.

Data in Table 8 indicate that the effects of different instant noodles seasoning formulae on the concentration of serum uric acid, urea and creatinine of rats. No significant variance between seasoning formulae 1, 2 and 3 (1.89, 2.00 and $1.95 \mathrm{mg} / \mathrm{dL}$, respectively), while the level of uric acid was significant decrease in rats group fed on seasoning formulae compared with rats fed on basal diet or commercial formula (3.23 and $3.90 \mathrm{mg} / \mathrm{dL}$, respectively).In the same trend, urea level in serum was significant decrease in rats groups fed on seasoning formula compared to basal diet and commercial formula. On the other view, serum creatinine was not significant concentrate between rats fed on seasoning formulae 1 , 
2 and 3 to basal diet group $(0.62,0.60,0.58$ and $0.68 \mathrm{mg} / \mathrm{dL}$, respectively), but rats fed on seasoning formula and basal diet group were significant decrease in serum creatinine concentrate compared to commercial formula group (1.02 $\mathrm{mg} / \mathrm{dL})$.

\section{Conclusion and Recommendations}

From the obvious results it is clear that onion, garlic, red chili, oregano, marjoram, basil, rosemary, cumin black pepper and their mixture formulae had highly amounts in natural antioxidants as polyphenolic and flavonoid compounds. Whereas, the biological experiment gave the best results using different formulas, showing healthy and acceptable taste for consumers avoiding the harmful additives of commercial formula.

\section{References}

[1] Velioglu, Y.S., Mazza, G., Gao, L. and Oomah, B.D. (1998) Antioxidant Activity and Total Phenolics in Selected Fruits, Vegetables, and Grain Products. Journal of Agricultural Food Chemistry, 46, 4113-4117. https://doi.org/10.1021/jf9801973

[2] Wang, H., Cao, G. and Prior, R.L. (1996) Total Antioxidant Capacity of Fruits. Journal of Agricultural and Food Chemistry, 44, 701-705. https://doi.org/10.1021/jf950579y

[3] Smith, R.J. and Winder, M.L. (1996) Medicinal Garden. In: Ober, R., Ed., The National Herb Garden Guidebook, The Herb Society of America, Inc., Springfield, 61-71.

[4] Hacskaylo, M.M. (1996) Culinary Garden. In: Ober, R., Ed., The National Herb Garden Guidebook, The Herb Society of America, Inc., Springfield, 79-93.

[5] Park, J.B. (2011) Identification and Quantification of a Major Antioxidant and Anti-inflammatory Phenolic Compound found in Basil, Lemon, Mint, Oregano, Rosemary, Sage and Thyme. International Journal of Food Science and Nutrition, 62 , 577-584. https://doi.org/10.3109/09637486.2011.562882

[6] Kivilompolo, M., Obůrka, V. and Hyötyläinen, T. (2007) Comparison of GC-MS and LC-MS Methods for the Analysis of Antioxidant Phenolic Acids in Herbs. Analytical and Bioanalytical Chemistry, 388, 881-887. https://doi.org/10.1007/s00216-007-1298-8

[7] Ejembi, D.I., Snni, M., Emmanuel, D., Friday, T. and Abbah, O. (2014) Evaluation of the Biochemical Composition and Proximate Analysis ofIndomie Noodle. International Journal Medical and Applied Science, 3, 166-175.

[8] Alabi, A.O., Edward, B.E., Oluwatobi, C.O. and Olutayo S.S. (2014) Assessment of the Mutagenic and Genotoxic Potential of Indomie Noodle Seasoning using Bacterial (Salmonella) Reverse Mutation and SOS Chromo Tests. Journal Innovative Biology, 1, 210-214.

[9] Sanni, M.E., Emmanuel, D., Friday, T. and Abbah, O. (2013) Effects of Chronic Administration of Indomie Noodles on the Activity of Alanine Aminotransferase of Rat Kidney. Journal Pharmaceutical Biomedical Sciences, 30, S65-S71.

[10] Singh, K.,Kaur, J., Ahluwalia, P. and Sharma, J. (2012) Effect of Monosodium Glutamate on Various Lipid Fractions and Certain Antioxidant Enzymes in Arterial Tissue of Chronic Alcoholic Adult Male Mice. Toxicology International, 19, 9-14. https://doi.org/10.4103/0971-6580.94507 
[11] FSA, (2008) "Board Discussion Color Advice" Food Standards Agency Website, (2011) "Tartrazine, the azo dye".

[12] Singleton, V.L., Orthofer, R. and Lamuela-Raventós, R.M. (1999) Analysis of Total Phenols and other Oxidation Substrates and Antioxidants by Means of Folin-Ciocalteu Reagent. Methods in Enzymology, 299, 152-178. https://doi.org/10.1016/S0076-6879(99)99017-1

[13] Pharmacopeia (1989) The State Pharmacopeia of USSR, Moscow, Pharmacopeia Part 2, 324-334. (C.F., Food Chemistry, 2004, 85, 231-237).

[14] Nagata, M. and Yamashita, I. (1992) Simple Method for Simultaneous Determinations of Chlorophyll and Carotenoids in Tomato Fruit. Nippon Shokuhin Kogyo Gakkaish, 39, 925-928. (C.F., Food Chemistry, 2006, 103, 413-419).

[15] Klein, B.P. and Perry, A.K. (1982) Ascorbic Acid and Vitamin A Activity in Selected Vegetables from Different Geographical Areas of the United Sates. Journal of Food Science, 47, 941-945. https://doi.org/10.1111/j.1365-2621.1982.tb12750.x

[16] ISO (2009): International Standard Organization (ISO 6571). Spices, Condiments and Herbs-Determination of Volatile Oil Content (Hydrodistillation Method).

[17] Yen, G.C. and Chen, H.Y. (1995) Antioxidant Activity of Various Tea Extracts in Relation to their Antimutagenicity. Journal of Agricultural and Food Chemistry, 43, 27-32. https://doi.org/10.1021/jf00049a007

[18] Desai, A.D., Kulkarni, S.S., Sahoo, A.K., Ranveer, R.C. and Dandge, P.B. (2010) Effect of Supplementation of Malted Ragi Flour on the Nutritional and Sensorial Quality Characteristics of Cake. Advanced Journal of Food Science and Technology, 2, 67-71.

[19] Reeves, P.G., Nielson, F.H. and Fahmy, G.C. (1993) Reports of the American Institute of Nutrition (AIN) Committee on Reformulation of the AIN 93 Rodent Diet Journal Nutrition, 123,1939-1951.

[20] Beutler, E. and Duron, O. and Kelly, B.M. (1963) Improved Method for the Determination of Blood Glutathione. Journal Laboratory Clinical Medicine, 61, 882-888.

[21] Nishikimi, M., Appaji, N. and Yagi, K. (1972) The Occurrence of Superoxide Anion in the Reaction of Reduced Phenazine Methosulfate and Molecular Oxygen. Biochemical Biophysical Research Communication, 46, 849-854. https://doi.org/10.1016/S0006-291X(72)80218-3

[22] Ohkawa, H., Ohishi, N. and Yagi, K. (1979) Assay for Lipid Peroxides. In: Animal Tissue by Thiobarbituric Acid Reaction. Analytical Biochemistry, 95, 351-358. https://doi.org/10.1016/0003-2697(79)90738-3

[23] Reitman, S. and Frankel, S. (1957) A Colorimetric Method Determination of Serum GOT (Glutamic Oxalacetic Transaminase) and GPT (Glutamic Pyruvic Transaminase) Activity. American Journal of Clinical Pathology, 28, 56-63. https://doi.org/10.1093/ajcp/28.1.56

[24] Belfield, A. and Goldberg, D.M. (1971) Revised Assay for Serum Phenyl Phosphatase Activity using 4-Amino-Antipyrine. Enzymology, 12, 561-586.

[25] Doumas, B.T., Watson, W.A. and Biggs, H.G. (1971) Albumin Standards and the Measurement of Serum Albumin with Bromcresol Green. ClinicaChimiaActa, 31, 87-89. https://doi.org/10.1016/0009-8981(71)90365-2

[26] Fossati, P., Orencipl, L. and Berti, G. (1980) Egyptian Colorimetric Method of Determination of Uric Acid in Serum. Clinical Chemistry, 26-227.

[27] Fawcett, J.K. and Scott, J.E. (1960) A Rapid and Precise Method for the Determination of Urea. Journal of Clinical Pathology, 13, 156-159. 
https://doi.org/10.1136/jcp.13.2.156

[28] Murray, R.L. (1984) Creatinine. In: Kaplan, L.A. and Pesce, A.J., Eds., Clinical Chemistry; Theory, Analysis and Correlation, CV Mosc by Co., St. Louis.

[29] Armitage, P.G., Berry, S. and Matthews, J.M. (2002) Statistical Methods in Medical Research. 4th Edition, Blackwell Science Ltd. https://doi.org/10.1002/9780470773666

[30] Masaki, H., Sakaki, S., Atsumi, T. and Sakurai, H. (1995) Active-Oxygen Scavenging Activity of Plant Extracts. Biological Pharmtheutical Bulletin, 18, 162-166. https://doi.org/10.1248/bpb.18.162

[31] Kappus, H. (1991) Lipid Peroxidation; Mechanism and Biological Relevance. In: Asuoma, O. and Halliwell, B., Eds., Free Radicals and Food Additives, Taylor and Francis, New York, 59-74.

[32] Peter, K.V. (2001) Handbook of Herbs and Spices. Woodhead Publishing Limited and CRC Press, Abington.

[33] Raghavan, S. (2007) Handbook of Spices, Seasonings and Flavorings.2nd Edition, CRC Press, Taylor \& Francis Group, Boca Raton.

[34] Li, S., Tan, H.-Y., Wang, N., Zhang, Z.-J., Lao, L., Wong, C.-W. and Feng, Y. (2016) The Role of Oxidative Stress and Antioxidants in Liver Diseases. International Journal Molecular Sciences, 16, 26087-26124.

[35] Milinkovic-Tur, S., Peric, V., Stojevevic, Z., Zdelar-Tuk, M. and Pirsljin, J. (2005) Concentration of Total Proteins and Albumin and AST, ALT and GGT Activities in the Blood Plasma of Mares during Pregnancy and Early Lactation. Veterinerski $A E H N, 75,195-202$.

[36] Dahiru, D., John, O.O. and Umaru, H.A. (2003) Effect of Hibiscus sabdariffa calyx Extract in $\mathrm{CCl}_{4}$ iInduced Liver Damage. Biochemistry, 15, 27-33.

[37] Ganong, W.F. (2006) Review of Medical Physiology. 21st Edition, Lange Medical Books; McGraw-Hill Medical Publishing Division, London, 652-663.

[38] Adebayo, J.O., Igunnu, A., Arise, R.O. and Malomo, S.O. (2011) Effects of Co-Administration of Artesunate and Amodiaquine on Some Cardiovascular Disease Indices of Rats. Food and Chemical Toxicology, 49, 45-48. https://doi.org/10.1016/j.fct.2010.09.022

[39] Bennett, P.H., Mogensen, C.E. and Keane, W.F. (1995) Prevention of Diabetic Renal Disease with Special Reference to Microalbuminuria. The Lancet, 346, 1080-1084. https://doi.org/10.1016/S0140-6736(95)91747-0

[40] Pagana, K.D. and Pagana, T.J. (1997) Mosby's Diagnostic and Laboratory Test References. 3rd Edition, Mosby-Year Book, Inc., New York. 